Genre Baru Kasidah Sufistik di Indonesia 2001-2010 | Ai Shidqi Farchah Fauziyyah

\title{
Genre Baru Kasidah Sufistik di Indonesia 2001-2010
}

\author{
Ai Shidqi Farchah Fauziyyah \\ Fakultas Adab dan Humaniora \\ UIN Sunan Gunung Djati Bandung \\ Email: aishidqifarchah28@gmail.com
}

\begin{abstract}
The process of Islamization has caused acculturation among the Nusantara and foreign culture. One of them is in the field of music, namely "Kasidah". Initially the kasidah only used a tambourine instrument (rebana), later in its development it was mixed with Western musical instruments (guitar, bass, keyboard and drums), its name became the modern kasidah. Along with the development of the times, the Kasidah also went through a process of deculturation. Where the kasidah is no longer unique to the rebana, musicians in Indonesia have left the tambourine and only use modern musical instruments. a new genre emerged in kasidah, namely pop kasidah. This study uses historical research methods, namely research models that study past events based on the traces they have left. This research method is carried out in four stages, namely heuristics, criticism, interpretation and historiography. In 2001, a Sufi Muslim music group was born with personnel from various countries, namely Dust. They use many musical instruments from various countries as well, this is what causes the music color of Dust to be different from the others.
\end{abstract}

Keyword : Kasidah, Music, Sufi 
Genre Baru Kasidah Sufistik di Indonesia 2001-2010 | Ai Shidqi Farchah Fauziyyah

\section{Pendahuluan}

Masyarakat Muslim tentu sudah mengetahui bahwa musik kasidah adalah salah satu bentuk seni Islam. Tentunya tidak mengherankan apabila seni kasidah ini selalu menampilkan lagu-lagu yang erat kaitannya dengan ajaran-ajaran Islam, terlebih lagi musik ini menjadi satu bentuk pertunjukan seni musik yang menunjukkan ciri khas bagi umat Islam. Pengkhususan ini tidak terlepas dari proses panjang yang telah terjadi pada bentuk kasidah sebagai musik Islam, yang telah mengalami pasang surut dalam proses perkembangannya hingga sekarang. Hal ini bisa menjadi satu kajian tersendiri, untuk menjelaskan bagaimana musik ini dapat bertahan sebagai musik Islam ditengah arus modernitas yang dialami musik populer. ${ }^{1}$

Semarak lagu-lagu kasidah semakin banyak terdengar sampai ke pelosok negeri, apalagi saat memasuki bulan Ramadan. Hampir setiap radio dan televisi swasta mengumandangkan dan menayangkan musik tersebut. Setelah memasuki dekade 70-an, musik ini berkembang menjadi satu bentuk musik yang bisa dimainkan dengan alat-alat modern (band). Bahkan beberapa musisi kondang menjadikan irama kasidah menjadi satu penampilan musik dengan warna baru. ${ }^{2}$

Adapun teori yang digunakan yaitu dekulturasi. Menurut Kodiron, dekulturasi adalah tumbuhnya unsur kebudayaan yang baru untuk memenuhi kebutuhan baru, yang timbul karena perubahan situasi. Musik rebana adalah jenis musik yang berasal dari musik yang bercirikan Islam yang ada sebelumnya, karena berakulturasi secara lokal dan budaya Arab, kemudian dalam kurun waktu yang panjang musik rebana mengalami proses dekulturasi. $^{3}$

Kasidah menurut KBBI adalah bentuk puisi berasal dari kesusastraan Arab, bersifat pujaan (satire, keagamaan) biasanya dinyanyikan (dilagukan). Pengertian kasidah semakin berkembang seiring berjalannya waktu menunjuk pada lagu serta musik dengan khasnya yaitu seni suara yang bernapaskan Islam, di mana lagu-lagunya banyak mengandung unsur-unsur dakwah islamiyah dan nasihat-nasihat baik sesuai ajaran Islam. Biasanya lagu-lagu itu dinyanyikan dengan irama penuh kegembiraan yang hampir

\footnotetext{
${ }^{1}$ Bambang Afrianto, "Musik Qasidah: Dari Media Dakwah Menjadi Hiburan,” n.d., 1.

2 "Lagu Kasidah Semakin Semarak," Pikiran Rakyat, January 1996, 4.

3 Kodiran, Akulturasi Sebagai Mekanisme Perubahan Kebudayaan (Yogyakarta: Humaniora, 1988), 90.
} 
menyerupai irama-irama Timur Tengah dengan diiringi rebana, yaitu sejenis alat tradisional yang terbuat dari kayu, dibuat dalam bentuk lingkaran yang dilobangi pada bagian tengahnya kemudian di tempat yang dilobangi itu di tempel kulit binatang yang telah dibersihkan bulu-bulunya. ${ }^{4}$

Saat ini perkembangan musik sedemikian maju, musik Barat tak terbendung masuk ke Indonesia dengan jenis musik hiburan yang modern dengan peralatan dan bentuk penyajian yang menarik, seperti: musik pop, jazz, rock blues, dangdut, keroncong bahkan campursari. Maka musik rebana dianggap sebagai musik bercirikan Islam pedesaan yang ketinggalan zaman, budaya pesantren tradisional, sehingga dianggap kurang representatif, kuno dan tidak diminati kaum muda. Dengan keadaan yang demikian, musik rebana mengalami perubahan diri, atau sebuah evolusi kecil dalam hal komposisinya sehingga ia mengalami proses akulturasi, yaitu membuat suatu perubahan bentuk dirinya dengan membuat perubahan baru dengan mengambil hal-hal yang baru. Selanjutnya musik rebana mengambil elemen-elemen musik Barat, terutama peralatan, bentuk penyajian, syair dan meninggalkan sebagian elemen-elemen musik rebananya, tetapi tetap mempertahankan ciri Islamnya, maka terbentuklah musik kasidah modern di Indonesia. $^{5}$

Dari fenomena di atas, timbul pertanyaan, apakah ada kelompok musik yang dapat menggabungkan antara kasidah tradisional dengan kasidah modern? Apakah dari penggabungan tersebut muncul genre baru dari musik kasidah?

Dari uraian-uraian di atas, penulis memfokuskan penelitian ini terhadap perkembangan kelompok musik Debu dengan segala keunikannya termasuk genre baru kasidah sufistik di Indonesia dari tahun 2001 sampai 2010.

\section{Metode}

Penelitian yang baik tentunya harus ditunjang dengan metode penelitian yang jelas dan terarah. Hal ini menjadi penting dilakukan sebagai proses dalam menghasilkan penelitian yang relevan dan dapat dipertanggungjawabkan secara ilmiah. Dalam penelitian ini penulis menggunakan metode penelitian kualitatif dengan metode historis. Menurut

\footnotetext{
4 "No Title," 2020.

${ }^{5}$ Susetyo, No Title, n.d., 3.
} 
Nugroho Notosusanto metode historis merupakan sekumpulan prinsip dan aturan yang sistematis dimaksudkan untuk memberikan bantuan secara efektif dalam usaha mengumpulkan bahan bagi sejarah, menilai secara kritis dan kemudian menyajikan suatu sintesa daripada hasil-hasilnya. ${ }^{6}$ Metode penelitian ini dilakukan melalui empat tahapan, yaitu heuristik, kritik, interpretasi dan historiografi.

Dalam penulisan sejarah, digunakan secara bersamaan tiga bentuk teknik dasar tulis-menulis yaitu deskripsi, narasi, dan analisis. Dalam penelitian ini penulis melakukan pendekatan dengan menggunakan pendekatan deskriptif-analitis. Oleh karena itu, selain lebih banyak berorientasi pada sumber-sumber sejarah, penulis juga melakukan analisis tentang perubahan yang terjadi pada dunia musik kasidah di Indonesia. Penafsiran yang digunakan adalah penafsiran sosiologis yaitu dengan mencoba melihat asal-usul, struktur dan kegiatan manusia dalam interaksinya dengan lingkungan fisiknya; masyarakat dan lingkungan fisik bersama-sama maju dalam suatu proses evolusi. ${ }^{7}$

\section{Hasil Penelitian dan Pembahasan}

\section{Sejarah Terbentuknya Kelompok Musik Debu}

Kelompok musik Debu adalah kelompok pemusik Muslim sufi yang sebagian anggotanya berasal dari luar Indonesia. Sebelum pindah ke Indonesia, sebagian besar anggotanya bertempat tinggal disebuah kota kecil di daerah New Mexico, sebuah provinsi yang terletak di antara Texas dan Arizona, Amerika Serikat. Di sana mereka tinggal di pesantren dan membentuk sebuah komunitas kecil yang mempelajari tasawuf di bawah bimbingan Syekh Fattah. Selain belajar tasawuf, Syekh Fattah juga membentuk komunitas musik bernama Dust on the Road dengan aliran klasik rock tetapi lirik-liriknya mengandung nilai-nilai sufistik. Menurutnya, bagi sufi menyanyi adalah ibadah dan bagian dari pengembangan spiritual. ${ }^{8}$

Dari kecil mereka sudah melakukan perjalanan dengan berpindahpindah dari satu negara ke negara lain yaitu Oregon, Texas, Washington

6 Nugroho Notosusanto, Nugroho Notosusanto, Masalah Penelitian Sejarah Kontemporer (Jakarta: Yayasan Penerbit UI, 1984), 11.

7 Helius Sjamsudin, Metodologi Sejarah, ed. M Nursam (Yogyakarta: Penerbit OMbak, 2012), bks. 123-132.

8 Arif Saripudin, Strategi Pementasan Grup Musik Islami Debu Sebagai Media Dakwah (Jakarta: UIN Syarif Hidahatullah Jakarta, 2008), bk. 56. 
State, California, kemudian kembali lagi ke Texas, dan pada 1990 mereka menetap di New Mexico. ${ }^{9}$ Pada 1997, sebagian dari mereka pindah ke Republik Dominika karena kehidupan masyarakat Amerika sangat liberal dan sekuler sehingga dianggap kurang cocok. Di sana mereka mempelajari bahasa Spanyol. Akan tetapi, di sana pun sama dengan kehidupan sebelumnya. Mereka menginginkan kehidupan yang nyaman dan tentram dengan suasana Islami. Setelah dua tahun di sana, mereka kembali pindah ke Amerika. ${ }^{10}$

Menurut Mustafa Daood, suatu malam Syekh Fattah mendapat ilham dari Tuhan untuk mengunjungi Indonesia. Namun, tidak ada satu pun dari mereka yang tahu di mana letak Indonesia. Mereka mencari tahu dengan mengandalkan jejaring internet dan menemukan homepage orang Indonesia yaitu Syekh Uqbah, kemudian menjalin hubungan pertemanan dan menyampaikan keinginan untuk datang ke Indonesia. ${ }^{11}$

Pada Maret 1999, mereka tiba di Jakarta dan tinggal di daerah Pasar Minggu selama tiga bulan. Selanjutnya, mereka dapat undangan dari Universitas Muslim Indonesia (UMI) Ujung Pandang untuk menjadi guru agama. Sesampainya di sana mereka ditempatkan di Bukit Barugah kemudian pindah ke daerah pedesaan di Padang Lampe dan tinggal di pesantren Darul Mukhlisin milik UMI. Banyak mahasiswa yang tinggal di sana tetapi mereka kekurangan tenaga pengajar di bidang keagamaan sehingga Syekh Fattah pun diminta untuk menjadi guru agama bagi mahasiswa UMI tersebut. Setiap hari mereka diajari membaca alquran, hadis serta bahasa Inggris. Setelah salat lima waktu, Syekh Fattah juga membimbing zikir para pengikutnya serta mahasiswa UMI. ${ }^{12}$

Mengamati pola perilaku mereka, Syekh Fattah menyadari pada umumnya mahasiswa itu tidak paham mendalam tentang Islam. Banyak mahasiswa yang tidak bisa membaca alquran dan tata cara salat. Oleh karena itu, ia menekankan zikir untuk menyentuh minat para mahasiswa terhadap keindahan Islam dengan cara melantunkan puji-pujian kepada Allah SWT dan nyanyian-nyanyian. Syair-syairnya mengandung nilai tentang adab dan

${ }^{9}$ https://www.youtube.com/watch?v=dKc18H71mrQ\&t=242s, Sebuah Nama Sebuah Cerita Part 1, Perjalanan Hidup, 2020.

${ }^{10}$ Saripudin, "Lihat Https://Www.Kampungcempluk.Com/Mustafa-Debu-MenyapaKampung-Dalam-Cempluk-Berbunyi-Kcf6/,” 2020, bk. 56.

${ }^{11}$ Saripudin, Sebuah Nama Sebuah Cerita Part 2, Perjalanan Hidup., 2020, 57.

${ }^{12}$ Saripudin, Sebuah Nama Sebuah Cerita Part 2, Perjalanan Hidup. 
Genre Baru Kasidah Sufistik di Indonesia 2001-2010 | Ai Shidqi Farchah Fauziyyah

akhlak serta uraian tentang Islam yang sejati sesuai pesan Nabi Muhammad SAW. Seiring berjalannya waktu mulai tertanam dalam jiwa mahasiswa yang suka berzikir. ${ }^{13}$

Pada 2001, mereka kembali ke Jakarta Selatan selama satu tahun. ${ }^{14}$ Syekh Fattah membentuk komunitas musik yang diberi nama Debu. Bagi Syekh Fattah Debu mempunyai arti tersendiri yaitu kendaraan yang Allah berikan yang sangat luar biasa sehingga membawa berkah yang tidak terhingga. ${ }^{15}$

Tujuan dibentuknya komunitas ini adalah dengan musik bisa mengajak manusia kepada Islam. Musik dipercaya menjadi media yang efektif dalam menyampaikan ajaran Islam, termasuk ajakan untuk meningkatkan keimanan kepada Tuhan. ${ }^{16}$

\section{Personil Kelompok Musik Debu}

Unik dan bersahaja begitu citra yang ditampilkan para personil Debu. Sebagian besar dari mereka berasal dari Amerika Serikat, ada pula dari Swedia, Inggris, dan Indonesia. sebelum datang ke Indonesia mereka adalah satu keluarga besar disanggar sufi yang dipimpin Syekh Fattah. Di Amerika mereka mengaku kesulitan untuk berkembang karena Muslim termasuk kaum minoritas. ${ }^{17}$

Oleh karena itu, sekitar 70 orang pindah ke Indonesia pada $1999 .{ }^{18}$ Setelah dua tahun tinggal di Indonesia, Syekh Fattah melihat para pemuda disekitar tempat yang ia tinggali sibuk dengan hal-hal yang tidak jelas sehingga ia memutuskan untuk membentuk komunitas musik berlatarbelakang sufi. Siapa saja boleh masuk ke dalam komunitas tersebut. ${ }^{19}$ Pada 2001 komunitas tersebut berubah menjadi kelompok musik yang diberi nama Debu dengan personil tetap sekitar 18 orang saja ( 10 wanita dan 8

${ }^{13}$ Saripudin.

${ }^{14}$ Dari Sulawesi pindah ke Jakarta Selatan pada 2001 tepatnya di daerah Pondok Indah, kemudian pada 2003 mereka pindah ke Depok sampai sekarang. Wawancara pribadi dengan Mustafa melalui telepon pada 19 Juli 2020.

${ }^{15}$ Wawancara pribadi dengan Mustafa melalui telepon pada 13 Juli 2020.

${ }^{16}$ Saripudin, Sebuah Nama Sebuah Cerita Part 2, Perjalanan Hidup.

${ }^{17}$ Saripudin.

${ }^{18}$ Sebuah Nama Sebuah Cerita Part 3, Perjalanan Hidup., 2020.

${ }^{19}$ Wawancara pribadi dengan Mustafa melalui telepon pada 14 Juli 2020. 
Genre Baru Kasidah Sufistik di Indonesia 2001-2010 | Ai Shidqi Farchah Fauziyyah

laki-laki). Namun biasanya pada saat manggung hanya 10 sampai 12 orang saja yang tampil. ${ }^{20}$

Adapun biodata personil Debu yaitu:

a. Kumyal Mustafa

Mustafa lahir pada 9 Juli 1981 di Oregon, Amerika Serikat. Ia dikenal dengan nama Mustafa Debu. Posisi dalam grupnya sebagai pemain gambus, biola, aranser musik dan lead vocalis. Mustafa adalah Debu, Debu adalah Mustafa. Dia memang lokomotif Debu, dalam setiap acara ia tidak lupa menyampaikan pesan-pesan Islam sebelum bernyanyi. Ketika nyanyian berlangsung ia selalu mengajak penonton untuk turut berzikir Laa ilaha illallah sehingga situasi berubah menjadi gema tahlil.

b. Daood Abdullah

Daood lahir di Texas, Amerika Serikat pada 28 September 1988. Dalam band Debu daood memegang alat perkusi, darbuka, serta drum tergantung alat apa yang diperlukan ketika manggung. Selain sibuk dengan grup bandnya, ia juga mengikuti sekolah drum disebuah sekolah musik di Jakarta milik musisi Dwiki Dharmawan. Tidak hanya drum saja ia juga belajar gitar flamenco dan gitar elektrik. Daood sendiri mempunyai ciri khas saat berada di atas panggung yaitu dengan kacamata hitamnya.

c. Fadhila Shirin

Fadhila Shirin lahir di Texas, Amerika Serikat pada 30 Maret 1989. Ia adalah seorang penyanyi sekaligus pemain biola dalam band Debu. Setelah pindah ke Indonesia, banyak penggemar Debu yang menyukainya karena paras cantiknya dan hampir setiap hari ia menerima surat dari para penggemarnya.

d. Hasniah Ali

Hasniah Ali merupakan penyanyi latar yang berasal dari Stockholm, Swedia. Ia lahir pada 11 mei 1975, selain pintar bernyanyi ia juga pandai membuat kue Swedia. Pada saat itu ia belum bisa tampil dengan personil lainnya karena beberapa hal. Untuk mengisi waktu luangnya ia gunakan untuk belajar alat beberapa alat musik.

e. Fatimah Husnia

${ }^{20}$ Saripudin, Sebuah Nama Sebuah Cerita Part 3, 2020, 59. 
Genre Baru Kasidah Sufistik di Indonesia 2001-2010 | Ai Shidqi Farchah Fauziyyah

Fatimah lahir di Texas, Amerika Serikat tahun 1987 tanggal 8 November. ia seorang keturunan Itali dan Malaysia yang mahir bermain baglama (saz) dan violin kadang-kadang ia juga belajar gendang.

f. Layla Wafiyah

Layla lahir pada 31 Desember 1969 di Washington, Amerika Serikat. Posisi dalam band Debu sebagai pemain harpa, kanoon, tamborin, sekaligus vokalis.

g. Maryam Ali

Maryam Ali adalah seorang penyanyi asal Oregon, Amerika Serikat lahir pada 15 Desember 1986. Ia merupakan penyanyi tetap grup band Debu.

h. Mujahid Abdullah

Menurut teman-temannya, Mujahid termasuk murid Syekh Fattah yang rajin. Ia berasal dari Michigan, Amerika Serikat lahir pada 10 November 1978. Ia seorang pemain bas dan seorang pengajar anakanak.

i. Naima Mahmoud

Naima Mahmoud lahir 29 Januari 1980 di Texas, Amerika Serikat. Ia seorang penyanyi, pemain gambus dan jumbush dalam band Debu.

j. Ibrahim Conway

Ibrahin Conway merupakan manajer grup band Debu setelah Najib Ali, ia lahir di Texas, Amerika Serikat pada 28 Desember 1982.

k. Najma Hakimah

Najma Hakimah lahir pada 31 Desember 1969 di Oklahoma, Amerika Serikat. Ia merupakan personil paling tua diantara personil lainnya. Posisi di dalam band miliknya yaitu sebagai pemain santoor, selain itu ia juga yang memimpin latihan accapela setiap pagi.

1. Naseem Nahid

Naseem merupakan seorang pemain perkusi dan penyanyi latar. Ia lahir di Washington DC, Amerika Serikat pada 4 Oktober 1976. Ia adalah salah satu yang bertanggung jawab mengelola surat-surat dari penggemar Debu. Selain itu ia juga mempunyai kelas khusus anak-anak untuk mengajar bahasa Inggris dan menulis.

m. Muhammad Saleem 
Genre Baru Kasidah Sufistik di Indonesia 2001-2010 | Ai Shidqi Farchah Fauziyyah

Muhammad Saleem lahir pada 15 Desember 1986 di Oregon, Amerika Serikat. Ia adalah adik dari Mustafa, sama seperti Mustafa ia juga seorang aranser lagu.

n. Syakura Yasirah

Syakura lahir di Michigan, Amerika Serikat 2 Juni 1981. Posisinya sebagai pemain biola dalam band Debu, ia juga merupakan personil tetap Debu.

o. Susan Fatimah

Susan Fatimah berasal dari Inggris yang lahir pada 31 Desember 1969. Awalnya ia hanya sebagai penyanyi latar dalam band Debu, berkat ketekunannya belajar alat musik organ, sekarang posisinya bertambah menjadi pemain keyboar.

p. Husayn Lee Larusa

Husayn Lee lahir pada 22 Agustus 1985 di Oregon, Amerika Serikat. Sejak pindah ke Indonesia ia lebih akrab dipanggil Ali, bakatnya adalah bermain perkusi sekaligus penyanyi latar.

q. Zakariyah aal Daood

Zakariyah lahir di New Mexico, Amerika Serikat pada 25 Maret 1991. Ia merupakan personil termuda di antara yang lain. Posisinya memang sebagai pemain perkusi tetapi ia juga bisa bernyanyi

r. Abdul Wahab

Abdul Wahab adalah orang Indonesia dari Jakarta, ia lahir di Bogor, 22 Juni 1986. Awalnya ia hanya seorang penggemar grup musik ini, ia sering datang ikut latihan setiap hari sampai akhirnya ia bergabung dengan Debu pada $2003 .^{21}$

\section{Alat Musik}

Alat-alat musik yang digunakan kelompok musik Debu berbeda dengan yang digunakan kelompok musik kebanyakan. Berbagai alat musik dari berbagai negara turut melengkapi keragaman musik Debu. Ketika masih di Amerika mereka sering melakukan perjalanan keluar kota bahkan lintas negara sehingga mereka banyak mengenal dan mempelajari alat musik.

Oleh karena itu, dalam perjalanan karirnya tidak hanya personil yang mengalami penambahan akan tetapi alat musik yang mereka gunakan juga mengalami perkembangan. Menurut Mustafa, ada beberapa alat musik yang

${ }^{21}$ Saripudin, “Http://Www.Kampungcempluk.Com/Tag/Musik-Debu/ D,” 2020, 6156. 
hanya digunakan ketika di Amerika saja saat nama mereka masih Dust on the Road yang terbentuk pada 1998, seperti Santur dari Iran, Tambura dan Baglama dari Turki. ${ }^{22}$ Setelah mereka pindah ke Indonesia pada 1999, alat musik pun mengalami perkembangan. Ketika mereka berada di Padang Lampe mereka belajar gambus (dalam bahasa Bugis disebut gendok-gendok) kepada orang Bugis. Sampai saat ini alat gambus selalu menjadi alat musik yang tidak pernah lepas ketika Debu tampil. Selain gambus alat yang wajib bagi Debu di antaranya, perkusi, viola, seruling bambu/nei. Pada 2001 mereka pindah ke Depok, disana juga mereka belajar seruling khas Sunda bersama teman mereka di Subang, alat ini juga menjadi alat wajib bagi Debu saat mereka tampil. ${ }^{23}$

Tidak hanya alat-alat tradisional saja yang mereka gunakan, alat musik seperti drum, keyboard, gitar dan bas juga mereka pakai agar semua kalangan terutama anak muda bisa menerima dan menikmati musik mereka. ${ }^{24}$

\section{Lagu dan Album}

Salah satu impian pemusik yaitu membuat lagu-lagu bahkan album, seperti halnya yang dilakukan kelompok musik Debu dalam upaya memanjangkan kariernya. Adapun lagu dan albumnya adalah sebagai berikut:

Pertama, album Mabuk Cinta, adalah album pertama yang dikeluarkan Debu pada 2003. Album ini terdapat dalam dua bahasa, bahasa Indonesia dan bahasa Arab.

Kedua, Makin Mabuk (Even More Drunk), album ini dirilis pada 2004., dibuat dengan tiga bahasa, yaitu bahasa Indonesia, bahasa Arab dan bahasa Inggris. ${ }^{25}$

Ketiga, Nyawa dan Cinta merupakan album ke tiga yang dirilis Debu pada 22 September $2006 .{ }^{26}$

Keempat, Gubahan Pecinta, album ini dirilis pada 2007 dan dibuat ke dalam empat bahasa yaitu Indonesia, Inggris, Arab, Turki, Cina dan Italia. ${ }^{27}$ Album ini berisi 13 lagu.

\footnotetext{
${ }^{22}$ Wawancara Pribadi dengan Mustafa melalui telepon seluler pada 19 Juli 2020.

${ }^{23}$ Wawancara Pribadi dengan Mustafa melalui telepon seluler pada 19 Juli 2020.

${ }^{24}$ Https://Www.Youtube.Com/Watch? V=I30TSonV-Ug, 2020.

25 "Debu Makin Mabuk," 2020.

26 "Debu Lancarkan Nyawa Dan Cinta," 2020.

27 “Tampil Memukau Di Padang," 2020.
} 
Genre Baru Kasidah Sufistik di Indonesia 2001-2010 | Ai Shidqi Farchah Fauziyyah

Kelima, Hep Beraber (Let's Say it Together), album ini digarap dalam empat bahasa pada 2007 yakni, Indonesia, Spanyol, Arab dan Iran. Aransemen musik dalam album ini pun menggunakan alat-alat musik tertentu yang mendekati pakem musik di negara bersangkutan. Seperti dalam bahasa Parsi menggunakan alat musik santur khas Iran, dalam bahasa Spanyol menggunakan alat musik gitar, meski begitu mereka tetap menampilkan ciri khas musik Debu yaitu menggunakan gambus dan perkusi. $^{28}$

Keenam, Dianggap Gila, album ini diluncurkan pada 2010. Menurut Mustafa, dari sudut musikalitasnya memakai beat-beat hiphop, rock, dan jazz. Namun tetap mempunyai ciri khas yaitu alat musik gambus dan perkusi tetap digunakan serta lirik-liriknya bersifat spiritual. ${ }^{29}$

\section{Kelompok Musik sebagai Genre Baru Musik Kasidah}

Seperti yang telah dijelaskan di atas -Perkembangan Kasidah di Indonesia- dari 1960-an sampai 2000 genre musik kasidah mengalami perkembangan. Hal ini disebabkan oleh prosesnya akulturasi sampai dekulturasi serta kemajuan teknologi yang semakin pesat. Perkembangan musik zaman dulu di Indonesia belum terlalu banyak tetapi dari masa ke masa dengan munculnya beberapa kondisi baik sosial maupun politik dapat memengaruhi warna-warni musik.

Debu adalah kelompok musik yang lahir di zaman kontemporer, mereka mempunyai genre musik yang khas, jenis musik yang mereka pilih sebenarnya berangkat dari sejak kecil ketika Syekh Fattah melarang untuk mendengar musik-musik biasa seperti pop dan lainnya, mereka hanya boleh mendengarkan musik yang tidak mereka paham dan musik-musik yang menggetarkan jiwa, seperti musik-musik Arab, Turki, Timur-Tengah, dan Spanyol. Oleh karena itu, genre musik Debu dipengaruhi oleh hal-hal tersebut. Akan tetapi, dalam industri musik internasional genre tersebut disebut dengan world music karena menggabungkan semua jenis musik. ${ }^{30}$

World music adalah genre musik yang membawakan aliran/warna musik tradisional yang kental dengan musiknya. Umumnya genre world music ialah seperti musik tradisional atau musik rakyat dari suatu budaya yang diciptakan dan dimainkan oleh musisi pribumi dan terkait erat dengan

28 "Debu Garap Album Empat Bahasa," 2020.

${ }^{29}$ Mustafa Daood dalam wawancara majalah Nova Jumat, 6 Agustus 2010 Pukul 11:42 WIB. Diakses pada 24 Januari 2020.

${ }^{30}$ Https://Www.Youtube.Com/Watch?V=I30TSonV-Ug, 
musik dari daerah asal mereka. Bisa pula dikatakan bahwa world music merupakan perpaduan/pengadaptasian musik tradisional dengan musik modern/Barat. Ada beberapa definisi yang saling dengan world music, salah satunya adalah bahwa hal itu terdiri dari "semua musik dunia luar", meskipun seperti membuat definisi yang luas kata tersebut hampir tidak berarti. Istilah ini juga diambil sebagai klasifikasi musik yang menggabungkan gaya musik populer Barat dengan salah satu genre dari berbagai genre musik non-Barat yang sebelumnya digambarkan sebagai musik rakyat atau musik etnis. Sebelum 1980-an, world music tidak jelas diidentifikasikan sebagai genre musik. Beberapa nama yang digunakan termasuk international music, ethnic music, atau folk. Hal ini tidak jelas siapa yang pertama kali menggunakan istilah world music, tetapi ada yang mengatakan dari 1984. Suatu tinjauan CD diterbitkan pada 27 Desember 1984 disebuah publikasi Jerman dari Hannover memproduksi kutipan dari perusahaan rekaman Jerman Exil Musik, "tonggak sejarah di jalan ke musik dunia", tinjauan yang lain diterbitkan di Jerman Frankenpost menggambarkan musik Dissidenten sebagai “... sebuah musik dunia baru yang harmonis. ${ }^{31}$

Istilah world music menjadi banyak digunakan sebagai alat pemasaran pada 1987. Menurut pendiri fRoots, Ian Anderson, eksekutif label rekaman Inggris Roger Amstrong (Ace Record) dan Ben Medelson (GlobeStyle) ketika mengadakan pertemuan di Inggris pada 1987 untuk membahas pembentukan sebuah genre musik baru. Pertemuan ini dihadiri oleh beberapa tokoh utama dalam dunia industri musik Inggris. Ada catatan sejarah pertemuan itu karena Ian Anderson menyimpan salinan tiap menit. Istilah world music diterjemahkan ke berbagai bahasa. Dalam bahasa Spanyol disebut musicas del mundo, Jerman menyebutnya welt music, dan Perancis menggunakan istilah musiques du monde. ${ }^{32}$

Musik dari seluruh dunia memberikan pengaruh lintah budaya luas sebagai gaya alami yang memengaruhi satu sama lain, dan beberapa tahun terakhir world music juga telah dipasarkan sebagai genre sukses. ${ }^{33}$

World music merupakan istilah yang sudah akrab bagi pemusik kontemporer dan para apresiatornya, mendapat tempat positif dalam

\footnotetext{
31 "No Title."

32 "No Title."

33 "No Title."
}

$384 \mid H$ is toria Madania Volume 4(2) 2020 
khazanah musik kontemporer Indonesia selama tahun 1998 lalu. Hal ini ditandai bukan saja oleh pendekatan fisikal, melainkan pula dari sisi konsep dan kinerja berkarya. Barangkali world music baru mengalami proses realisasi setelah pada 70-80-an mendapat perhatian dari sisi gagasan untuk berkarya. $^{34}$

Kulturalisme dan silang budaya -juga etnosentrisme- merupakan isu yang termasuk sentral di dalam kajian sosiologi masa kini terutama posmodernisme. Para pemusik kontemporer pun ikut menggarap isu tersebut dengan penuh semangat. Barangkali, Paul Gutama Soegijo yang begitu bersungguh-sungguh mengetengahkan musik silang budaya itu. Menurut Dieter Mack, meskipun istilah tersebut masih dapat diperdebatkan karena menghasilkan pendekatan berbeda-beda, tetapi hasil yang baik mestilah diperhatikan secara bersungguh-sungguh pula. Inti di dalam isu kulturalisme dan silang budaya ialah upaya kuat memunculkan ciri setempat. Rasa percaya diri etnik yang memang menguat pada paruh akhir tahun 90-an muncul di mana-mana, tidak hanya musik, melainkan pula film, seni rupa, seni pertunjukan, tari dan lain-lain. Fenomena kebangkitan Asia adalah salah satu ciri kecil adanya kesadaran bangga menjadi bangsa mandiri, dengan ciri budaya mandiri pula, tidak bergantung dan terpengaruh budaya Barat yang tetap mendominasi di mana-mana. ${ }^{35}$

Irwansyah merupakan komposer yang menggali musik dari khazanah sufi Melayu secara sangat baik dan interpretatif. ${ }^{36}$ Ia berasal dari Batak yang sejak kecil sudah menyukai musik. Pendalamannya pada musik Batak ia mulai sejak kuliah di Fakultas Sastra (sekarang Fakultas Ilmu Budaya) Universitas Sumatera (USU). Di masa itu ia berguru kepada Marsius Sitohang, seorang maestro musik Batak, untuk mempelajari musik perkusi taganing. Selain itu ia juga aktif di Lembaga Kesenian USU yang mempelajari musik Batak lainnya. Ia pun menekuni ensembel gordang sambilan khas Mandailing kepada Dagar Lubis. Kemudian ia melanjutkan studi musik program master etnomusikologi di Universitas Washington, Seattle, Amerika Serikat. Di sana ia mendalami aneka musik tradisi dunia

${ }^{34}$ Masyarakat Seni Pertunjukan Indonesia, Direktori Industri Musik (Masyarakat Seni Pertunjukan Indonesia (MSPI) bekerja sama dengan arti.line, 1999), 15.

35 Masyarakat Seni Pertunjukan Indonesia, Direktori Industri Musik (Masyarakat Seni Pertunjukan Indonesia (MSPI), 1999, 15-16.

${ }^{36}$ Masyarakat Seni Pertunjukan Indonesia, Direktori Industri Musik (Masyarakat Seni Pertunjukan Indonesia (MSPI). 
atau world music, antara lain belajar qawwali, nyanyian sufi Pakistan dari Nusrat Fateh Ali Khan. ${ }^{37}$

Sekembalinya ke Indonesia, Irwansyah dan istrinya Rithaony Hutaluju mendalami seni vokal. Pada 1995 membentuk kelompok musik Suarasama, kelompok musik ini mengkreasi musik-musik tradisi dunia. Melalui Suarasama, komposisi world music dengan warna tradisi Batak karya Irwansyah dikenal dunia. Kiprah Irwansyah berlanjut dalam sebuah pertunjukan "Kisah Lima Kota" yang menampilkan tari, teater, musik dari lima kota di Indonesia. pertunjukan itu sendiri diadakan di Bandung. Irwansyah dianggap membawa angin segar di dalam pendekatan terhadap musik tradisional. Bukan sebuah kebetulan apabila ia mendekati musik tradisional dari banyak budaya, baik dari leluhurnya Sumatera, kemudian ke Pakistan, dan Arab sekaligus. ${ }^{38}$

Pendekatan multikulturaisme Irwansyah itu menghasilkan sintesa musik tradisional yang memiliki nilai kekinian yang kenal, tidak asal tempel dengan renungan interpretasi mendalam. Pendekatan agama (Islam, terutama sisi esoterik sufisme) merupakan sesuatu yang sangat vital di dalam penciptaan Irwansyah. Adanya persamaan melodi dan instrumental antara musik Sumatera (gambus) dan Pakistan (qawwali), rupanya benar-benar dimanfaatkan olehnya. Bahkan istilah-istilah yang diusung pun merupakan kekayaan dari budaya kuno Islam kedua negeri. Perkawinan dua jenis musik itu rupanya menghasilkan paduan musik yang saling mengisi, dan dapat berbagi secara seimbang. Dari etnik lain, ia mengeksplorasi komposisi musik Sunda dengan menggunakan kendang. ${ }^{39}$

warna musik yang dikembangkan Irwansyah sama dengan warna musik Debu yaitu menggunakan pendekatan agama (Islam, sufisme). Debu merupakan kelompok musik akulturasi yang multikultur. Genre musik Debu ini dipengaruhi oleh beberapa faktor, yaitu (1) latarbelakang para personil sebagai orang-orang yang belajar tasawuf; (2) para personil yang berasal dari beberapa negara (Amerika, Inggris, Swedia, dan Indonesia) dengan membawa kebudayaannya masing-masing; serta (3) alat musik yang digunakan pun berasal dari berbagai negara pula sehingga menyebabkan

\footnotetext{
37 “Irwansyah Berharap Musik Sebagai Dunia Ekpresi Dan Pengetahuan,” 2020.

38 "Irwansyah Berharap Musik Sebagai Dunia Ekpresi Dan Pengetahuan."

${ }^{39}$ Masyarakat Seni Pertunjukan Indonesia, Direktori Industri Musik.
} 
Genre Baru Kasidah Sufistik di Indonesia 2001-2010 | Ai Shidqi Farchah Fauziyyah

warna musiknya sangat beragam mulai dari musik Turki, Iran, bahkan Indonesia.

Selain bergenre world music jenis musik Debu tidak bisa disebut gambus, kasidah atau nasyid. Mereka mempunyai warna tersendiri tetapi tidak bisa dikatakan juga sebagai musik sufi karena musik sufi Pakistan dan sufi Turki berbeda begitu pun musik sufi Afrika sangat berbeda sekali. Kalau pun masyarakat menyebut Debu sebagai kelompok musik sufi akan tetapi musik sudi ala Debu. ${ }^{40}$

\section{Simpulan}

Berdasarkan hasil penelitian dan pembahasan dapat disimpulkan bahwa, Debu merupakan kelompok musik Muslim Sufi yang personilnya berasal dari berbagai negara, yaitu Amerika, Swedia, Inggris dan Indonesia. Debu merupakan kelompok musik yang mencoba menggabungkan antara kasidah tradisional dengan kasidah modern, kemudian muncul genre baru dalam musik kasidah yaitu world music. Perubahan tersebut diakibatkan oleh akulturasi antara budaya Islam dengan budaya Nusantara. Kasidah hanya menggunakan alat rebana saja, kemudian pada perkembangannya mengalami percampuran dengan alat musik Barat (gitar, bas, keyboard dan drum), namanya pun menjadi kasidah modern. Seiring berkembangnya zaman, kasidah pun mengalami proses dekulturasi. Di mana kasidah tidak lagi khas dengan rebananya, musisi-musisi di Indonesia sudah meninggalkan rebana dan hanya menggunakan alat musik modern saja. muncullah genre baru dalam kasidah, yaitu pop kasidah.

\section{Daftar Sumber}

Arif Saripudin. Strategi Pementasan Grup Musik Islami Debu Sebagai Media Dakwah. Jakarta: UIN Syarif Hidahatullah Jakarta, 2008.

Bambang Afrianto. "Musik Qasidah: Dari Media Dakwah Menjadi Hiburan," n.d.

"Debu Garap Album Empat Bahasa," 2020.

"Debu Lancarkan Nyawa Dan Cinta," 2020.

"Debu Makin Mabuk," 2020.

https://www.youtube.com/watch?v=dKc18H71mrQ\&t=242s. Sebuah Nama

Sebuah Cerita Part 1, Perjalanan Hidup, 2020.

${ }^{40}$ Https://Www.Youtube.Com/Watch?V=I30TSonV-Ug, . 
Genre Baru Kasidah Sufistik di Indonesia 2001-2010 | Ai Shidqi Farchah Fauziyyah

Https://Www.Youtube.Com/Watch?V=I30TSonV-Ug, 2020.

"Irwansyah Berharap Musik Sebagai Dunia Ekpresi Dan Pengetahuan," 2020.

Kodiran. Akulturasi Sebagai Mekanisme Perubahan Kebudayaan. Yogyakarta: Humaniora, 1988.

“Lagu Kasidah Semakin Semarak.” Pikiran Rakyat. January 1996.

Masyarakat Seni Pertunjukan Indonesia. Direktori Industri Musik. Masyarakat Seni Pertunjukan Indonesia (MSPI) bekerja sama dengan arti.line, 1999.

—. Direktori Industri Musik (Masyarakat Seni Pertunjukan Indonesia (MSPI), 1999.

"No Title," 2020.

Nugroho Notosusanto. Nugroho Notosusanto, Masalah Penelitian Sejarah Kontemporer. Jakarta: Yayasan Penerbit UI, 1984.

Saripudin. "Http:/Www.Kampungcempluk.Com/Tag/Musik-Debu/～D," 2020.

-. "Lihat Https://Www.Kampungcempluk.Com/Mustafa-DebuMenyapa-Kampung-Dalam-Cempluk-Berbunyi-Kcf6/," 2020.

—. Sebuah Nama Sebuah Cerita Part 2, Perjalanan Hidup., 2020.

—. Sebuah Nama Sebuah Cerita Part 3, 2020.

Sebuah Nama Sebuah Cerita Part 3, Perjalanan Hidup., 2020.

Sjamsudin, Helius. Metodologi Sejarah. Edited by M Nursam. Yogyakarta:

Penerbit OMbak, 2012.

Susetyo. No Title, n.d.

"Tampil Memukau Di Padang," 2020. 